\title{
Estimates of Labor and Total Factor Productivity by 72 industries in Korea (1970-2004)
}

\author{
Hak K. Pyo and Keun Hee, Rhee*
}

\begin{abstract}
As Krugman (1994), Young (1994), and Lau and Kim (1994)'s studies showed, the East Asian economic miracle may be characterized as 'input-led' growth. However, both the stagnation in investment and the decrease in average working hours combined with decrease in the fertility rate require a productivity surge for a renewed sustainable growth in East Asia. The purpose of our study is to identify the sources of economic growth based on a KLEMS model for the Republic of Korea which experienced a financial crisis in 1997 after joining OECD. We report estimates of KLEMS inputs and gross output in Korea based on preliminary dataset of $72-$ industry classification following EU KLEMS project guidelines. We also provide estimates of 72 industry - level labor productivity and total factor productivity. We have found that Korea's catch-up process with industrial nations in its late industrialization has been predominantly input-led and manufacturing based as documented in Timmer(1999) and Pyo (2001). We have also found that TFP growth has been positively affected by the growth of labor productivity and output growth. However, since its financial crisis in December 1997, the sources of growth seem to have switched to TFP-growth based and IT-intensive Service based. But lower productivity in service industries due to regulations and lack of competition seems to work against finding renewed sustainable growth path.
\end{abstract}

JEL-Classification: O14, O47

Key-Words: Labor Productivity, Total Factor Productivity, Sustainable Growth

*Seoul National University, Korea Productivity Center. An earlier version of this paper was presented at OECD Workshop on Productivity Analysis and Measurement, Bern, 16-18 October 2006. We acknowledge financial support by the Bank of Korea and Korea Institute of International Economic Policy and research assistance of Eunkyung Jeon and Sun Young Jung at Seoul National University. pyohk@plaza.snu.ac.kr for correspondence. 


\section{Introduction}

In recent years, especially since the 1997 economic crisis in the East Asian countries including Korea, considerable changes have taken place in the Korean economy, such as investment stagnation (see e.g. Pyo (2006) Pyo and $\mathrm{Ha}$ (2005)), changes in production input patterns, and so on. One of the most important changes is the demand for high productivity, which would compensate the recent slowdowns of growth rates in capital and labor inputs. As Krugman (1994), Young (1994), and Lau and Kim (1994) showed, the East Asian economic miracle may be summarized as 'input-led' growth. Korea was no exception in this respect of growth pattern.

However, both the stagnation in investment and the decrease in average working hours require a productivity surge for long-term growth in Korea. In addition, a sharp decrease in the fertility rate in Korea necessitates productivity increase in order to improve the present income level and facilitate the support of the large elderly population by the small numbers of working age adults. For these reasons, 'productivity-driven' growth is indispensable for Korea. According to Lewis (2004), the fast economic growth in Korea is the result of both large labor input and capital accumulation. He argues that the average working hours is $40 \%$ higher than that of the U.S., and almost a third of GDP has been allocated to investment, while GDP per capita in Korea is about half of the U.S. GDP per capita. The focus is changing from how much inputs are put into production to how well those are organized.

The purpose of this paper is to explain the data structure of Korea for the estimation of productivities by industry in KLEMS model and present preliminary estimates of labor productivity and total factor productivity (TFP) at reasonably detailed industry level. We have used 72-sector industrial classification following the guidelines of EU KLEMS project for the future comparability with EU member countries, the United States, and Japan. Therefore, an analysis based on detailed industrial classification gives us better views on productivity and growth, which is difficult to grasp in broader industrial classifications. Industries in an economy have shown different productivity trends and growth patterns according to their characteristics of production, competition policies, and other economic and non-economic circumstances.

KLEMS model is a kind of gross output growth accounting in which output is measured by gross output and inputs are decomposed by capital (K), labor (L), 
energy $(E)$, material $(M)$, and service $(S)$. Since this methodology is basically based on gross output, it has the advantage of eliminating effects of intermediate inputs from other industries on productivity, therefore allowing productivities by industry to be more accurate. Moreover, the assumption on real value-added production function (separability assumption) is not usually guaranteed ${ }^{1}$, which also gives legitimacy to gross output growth accounting. However, gross output growth accounting requires more information on intermediate inputs than value-added growth accounting. Therefore, the data structure for estimating productivity has to be consistent with not only national income accounts but also input-output tables, Use and Make Matrix etc. and the estimation methodology for unavailable data should be examined more carefully.

We have found that Korea's catch-up process with industrial nations in its late industrialization has been predominantly input-led and manufacturing based. We have also found that TFP growth has been positively affected by the growth of labor productivity and output growth. However, since its financial crisis in December 1997, the sources of growth seem to have switched to TFP-growth based and IT-intensive Service based. But lower productivity in service industries due to regulations and lack of competition seems to work against finding renewed sustainable growth path.

This paper is organized as follows. Section 2 examines data structure including the methodology of measuring gross output by industry from InputOutput Tables and National Accounts published by the Bank of Korea and input measurements. Section 3 presents the estimates of labor productivity and TFP by 72 -industry and examines the relations between labor productivity and TFP and between output growth and TFP growth by periods. Section 4 concludes the paper.

\section{Data Structure}

\subsection{Gross Output Data}

\footnotetext{
${ }^{1}$ See Berndt and Christensen (1973,1974), Berndt and Wood (1974), Denny and Fuss (1977), and Yuhn (1991) for the U.S., and Pyo and Ha (2006) for Korea
} 
National Accounts by the Bank of Korea $(1999,2004)$ report annual series (1970-2002) of nominal gross outputs at basic prices, both nominal and real value-added at basic prices, nominal compensation of employees, and operating surplus at current prices of 21 industries including 9 manufacturing industries. Those data can be extended to the year 2005 from ECOS (Economic Statistics System) in the Bank of Korea website ${ }^{2}$. National Accounts (1987, 1994, 1999, 2004) also reports annual series (1985-2002) of both nominal and real Make Tables (V-Tables) and real Use Tables (U-Tables).

In addition to nominal gross output and both nominal and real value-added, real gross output at basic prices and real intermediate inputs at purchase prices can be obtained from Use Tables. However, since Make Tables and Use Tables for the years 1970-1984 and 2003-2004 are unavailable, we have generated them through RAS method using annual data from National Accounts and InputOutput Tables, and benchmark tables of 1985 and 2000, respectively. As the published Use Tables of National Accounts in Korea present the Domestic and Import Use Tables combined, we have not been able to isolate them into two separate tables. In the case of Use Tables before 1995, all the intermediate commodity inputs by industry are measured at purchase prices. Since 1995, those inputs have been measured at incomplete basic prices in the sense that those inputs include trade and transportation margins but isolate net production tax to the last row of intermediate input matrix. Because we have no information for transformation of the Use Tables from purchase prices to basic prices before 1995 and the Use Tables after 1995 have been measured at incomplete basic prices, we have changed the Use Tables at basic price after 1995 into Use Tables at purchase price allocating net production tax to each commodity proportional to each volume.

The trend of gross output has been shown in Figure 1. There was no real break in gross output growth in Korea's economy-wide economic performance except in the year 1998 after the financial crisis in December 1997. Even during the years of first oil crisis of 1974-1975 and the second oil crisis of 1980-1981, the Korean economy's real gross output continued to grow without major setbacks. After the economic crisis of December 1997, Korean economy had to go through IMF-mandated adjustment and restructuring program as

${ }^{2}$ http://www.bok.or.kr 
documented in Pyo (2004). We observe that even though economy-wide labor productivity continues to grow, the disparity between labor productivity in Manufacturing and that in Service has been widening. As the IMF-mandated restructuring in Manufacturing sector has improved on labor productivity gain through cut-back of unnecessary manpower, the restructuring in most of Service sectors except a few IT-related finance and communication sectors has been lagging behind.

Figure 1 Trend of Real Gross Output (2000 prices)

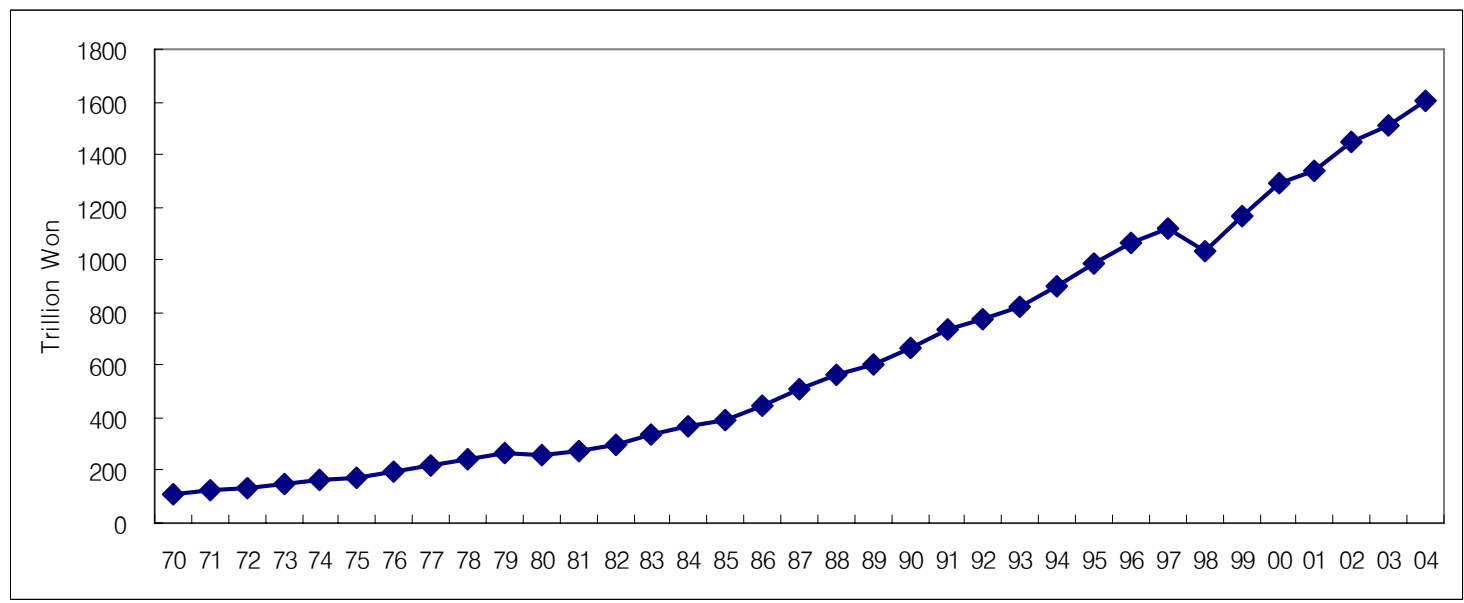

\subsection{Measurement of Capital Input}

The success of late industrialization by newly industrializing economies could not have been made possible if both the rapid accumulation of capital and its changing distribution among sectors were not realized in their development process. However, it is difficult to identify these factors empirically because the time series data of capital stocks in fast-developing economies by both types of assets and by industries are not readily available. The lack of investment data for a sufficiently long period of time to apply the perpetual inventory estimation method was the main cause of the problem. However, the National Statistical Office of the Republic of Korea has conducted nation-wide national wealth survey four times since 1968. Korea is one of a few countries which have conducted economy-wide national wealth surveys at a regular interval. Since the first National Wealth Survey (NWS) was conducted in 1968, the subsequent surveys were made in every ten years in 1977, 1987, and 1997, respectively. Since such regular surveys with nation-wide coverage are very rare in both 
developed and developing countries, an analysis on the dynamic profile of national wealth seems warranted to examine how national wealth in a fast growing economy is accumulated and distributed among different sectors.

The estimation of national wealth by types of assets and by industries was made by Pyo (2003) by modified perpetual inventory method and polynomial benchmark year estimation method using four benchmark-year estimates. We have extended his estimates to the year 2004, and changed the base year from 1995 to 2000. Since the database of Pyo (2003) covers 10 broad categories of industrial sector together with 28 sub-sectors of Manufacturing, it has been reclassified and reconciled with 72 industry classification using other sources such as Mining \& Manufacturing Census and Surveys, Wholesale and Retail Surveys, and so on. We have classified assets into five categories; residential building, non-residential building, other construction, transportation vehicles, and machinery, while excluding large animals \& plants, household durables, and inventory stocks. We have used estimated depreciation rates in Pyo as shown in Table 1.

\begin{tabular}{lccc}
\multicolumn{4}{c}{ Table 1 Estimated Depreciation Rates of Assets (Unit:\%) } \\
\hline & $1968-1977$ & $1977-1987$ & $1987-1997$ \\
\hline \multicolumn{1}{c}{ Total } & 5.1 & 5.7 & 4.6 \\
Residential Building & 5.5 & 1.2 & 3.3 \\
Non-residential Building & -6.7 & -1.3 & 3.0 \\
Other Construction & 9.7 & 8.4 & 1.0 \\
Transportation Vehicles & 49.3 & 28.7 & 16.9 \\
Machinery & 1.1 & 11.4 & 9.2 \\
\hline
\end{tabular}

Source: Pyo(2003)

In order to derive capital service inputs from capital stocks, we have followed the method of Jorgenson, Ho, and Stiroh (2005) except the adjustment for a rapid IT asset price decline. The capital service flows for each asset have been estimated from the capital stocks, and have been aggregated over all the assets assuming that the flow of capital service is proportional to the average of current 
and one-year lagged capital stocks, which means that currently installed capital stock is available in the midpoint of the installed period. We have estimated the price of capital service through the user cost of capital formula. This methodology derives the cost of capital by the equality between two alternative investments: earning a nominal rate of return and investing in asset earning a rental fee and selling the depreciated asset. We have used yields of corporate bonds for nominal rates of return and Pyo's (2003) results for depreciation rates as shown in Table 1. We did not consider tax effects in estimating cost of capital for the unavailability of data.

\subsection{Measurement of Labor Input}

In order to measure labor input for KLEMS model, we have to obtain both quantity data of labor input such as employment by industries and hours worked and quality factors such as sex, education and age. Both availability and reliability of labor statistics in Korea have improved since 1980. But the measurement of labor input by industries cannot be readily made because the statistics of employment by industries are not detailed enough to cover 72 sectors. Therefore, we have used other sources for breaking down the labor data. More detailed classifications of employment will have to rely on Employment Table, which is published as a supporting table to Input-Output Table. But it is available only every five year when main Input-Output Tables are published. Mining and Manufacturing Census and Survey by National Statistical Office also report employment statistics but it is limited to mining and manufacturing only.

Economically Active Population Yearbook by National Statistical Office reports the number of employment, unemployment, not-economically-active population and economically active population. Report on Monthly Labor Survey by Ministry of Labor publishes monthly earnings and working days of regular employees. Survey Report on Wage Structure by the same ministry reports wages. Nominal wages are also available from this survey. For the present study, we have obtained the raw data file of Survey Report on Wage Structure from the Ministry of Labor and Economically Active Population Survey from National Statistical Office for the period of 1980-2004. The data are classified by two types of gender (Male and Female), three types of age (below 30, 30-49, and 50 above), and three types of education (middle school and under, high 
school, college above) and, therefore, there is a total of 18 categories of labor as shown Table 2.

Since the raw-data file of the Survey Report on Wage Structure contains more detailed industrial classification than that of the Economically Active Population Survey, we have calculated the quantity of labor from the Economically Active Population Survey and the quality of labor from the Survey Report on Wage Structure. This enables us to include self-employed labor as well as to use more detailed data. However, since the Survey Report on Wage Structure does not include Agriculture and Government sectors, we had to use the average value of the entire economy for the quality measure of these two sectors. In order to make quality adjustments to the employment data, we have taken the method of Jorgenson, Gollop, and Fraumeni (1987)

Table 2. Classification of Labor Input

\begin{tabular}{|c|l|}
\hline & \multicolumn{1}{|c|}{ Categories } \\
\hline Gender & (1) male $\quad$ (2) female \\
\hline Age & (1) below 30 (2) 30-49 (3) above 50 \\
\hline Education & $\begin{array}{l}\text { (1) Low-skilled (middle school and under) } \\
\text { (2) Middle-skilled (high school) } \\
\text { (3) High-skilled (college above) }\end{array}$ \\
\hline
\end{tabular}

\subsection{Energy, Material, and Service and Input Shares}

In order to decompose intermediate inputs into energy (E), material $(M)$, and service (S) inputs, we have identified coal and lignite, crude petroleum and natural gas, uranium and thorium ores, metal ores, coke, refined petroleum products and nuclear fuel, gas, water, and electricity commodities as energy inputs, both primary commodities and remaining manufacturing commodities as material inputs, and remaining service inputs as service inputs.

Regarding shares of inputs, we have used compensation of employees as shares of labor inputs and remaining value-added as shares of capital inputs. This method may underestimate the shares of labor input by allocating the compensation of self-employed to the shares of capital input, and this gap would be especially large in primary industry. There are some adjustment 
processes to correct underestimation of labor share as attempted by, for example Harberger (1978), but we have not applied it in order to avoid arbitrary adjustments. This can be improved in future studies. As for energy, material, and service inputs, we have used nominal inputs for their own shares.

\section{Estimates of Labor Productivity and TFP by 72-industry}

\subsection{Trend of Labor Productivity Level and Growth Rates by Sector}

\section{(1) The Level and Trend of Labor Productivity}

As shown in Figure 2, the general trend of labor productivity reveals a rising trend but with a remarkable difference between Manufacturing and Service. While the labor productivity level in Manufacturing measured as the ratio of real price output to working hours increased sharply, the level in Service increased very slowly. The role of productivity gain in Manufacturing in the catch-up process of Korea has been well-documented by Timmer (1999) and Pyo (2001). As observed in Pyo and $\mathrm{Ha}$ (2005), the labor productivity level was not reduced during the years (1997-1998) of the Asian Financial Crisis because of IMFmandated industrial restructuring: the reduced output was matched by reduced employment leaving labor productivity level unaffected.

\section{Figure 2 Trend of Labor Productivity Level}

<unit: gross output per hour(won)>

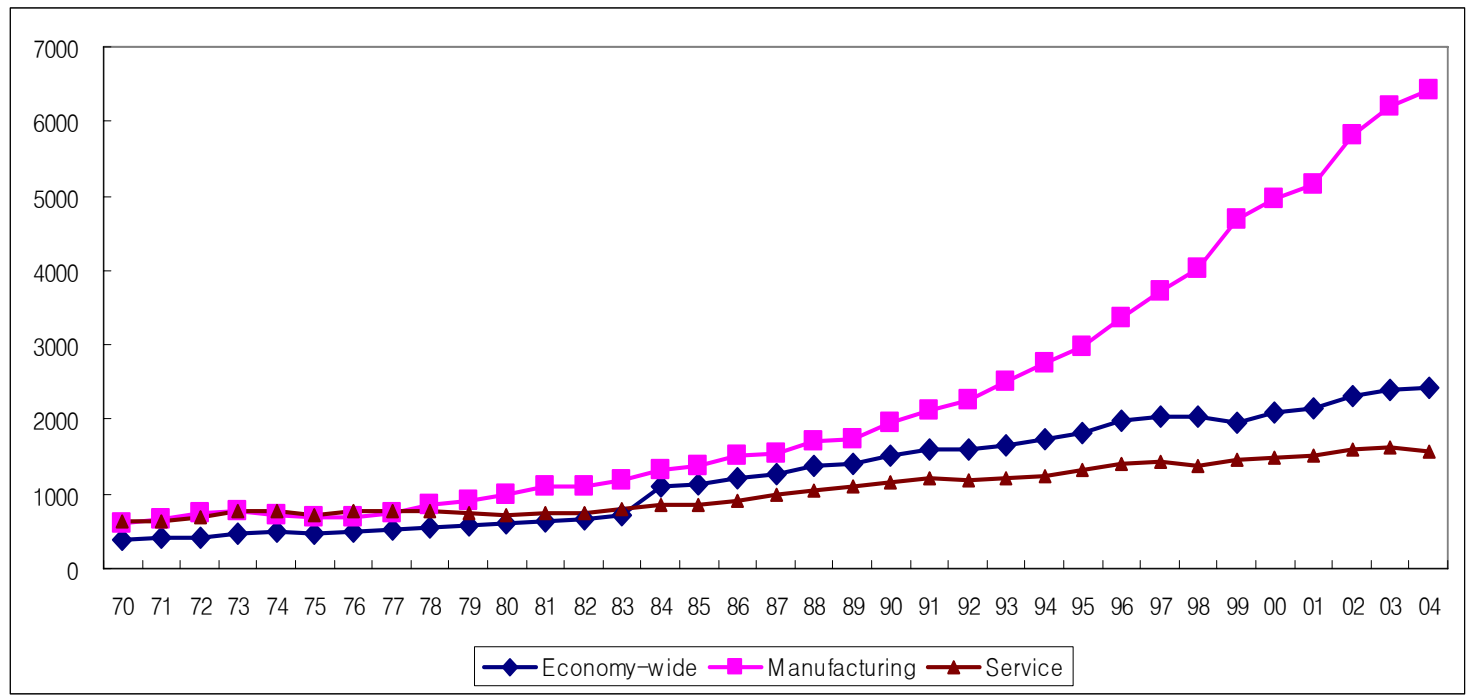


The relatively sluggish productivity gain in Service sector has been pointed out by IMF in their recent consultation with the Korean authorities as a bottleneck of sustainable growth for Korea. Inklaar, Timmer and van Ark (2006) also pointed out the slower productivity gain of service industries in Europe relative to those in the United States. A more detailed decomposition of labor productivity by sector and by sub-period is presented in Table 3. According to Kim(2006), while the share of Service sector in Korean economy has increased sharply reaching 56 percent level of GDP and 65 percent of total employment in 2005 , the Service productivity is not only low in level terms compared to industrial nations' levels but also lags behind in terms of growth rate. She also points out that Korea's inter-industry linkage effect between Manufacturing and Service is also only about half the size of industrial nations.

\section{(2) The growth rates of labor productivity by Sector}

The growth rates of labor productivity as summarized in Table 3 and shown in more detail in Figures $A-1$ and $A-2$ in Appendix confirm the remarkable difference between Manufacturing and Service sector. Throughout the entire period of 1971-2004, the economy-wide labor productivity has grown at the average rate of 5.41 percent but with the sectoral difference between Manufacturing $(6.88 \%)$ and Service $(2.63 \%)$. The difference did not shrink but rather has expanded as the process of industrialization continued. For example, the difference in the 1990's (9.86 \% vs. $2.82 \%$ ) has been more than doubled since 1970 's (4.15\% vs. $1.77 \%$ ).

The observed difference in both levels and growth rates of labor productivity between Manufacturing and Service can signal the difference in the degree of foreign competition, the proportion of tradable and non-tradable and the degree of domestic competition due to historically different regulatory environments. For example, the proportion of public enterprises and their subsidiaries in total output of many service industries such as utilities (electricity, water and gas), transportation and communication is a lot greater than their proportion in Manufacturing so that their productivity improvement could have been sluggish over time. In addition, many non-tradable sectors of service industries such as retail trade, real estate and financial services, hotels and restaurants etc. have been subject to all kinds of regulations such as zoning, sanitary standards and segregated financial market services etc. 
Table 3 Growth Rates of Labor Productivity by Sector

\begin{tabular}{cccc} 
Period & Economy-wide & Manufacturing & Service \\
\hline $71-79$ & 4.69 & 4.15 & 1.77 \\
$80-' 89$ & 8.77 & 6.67 & 3.72 \\
$90-' 99$ & 3.32 & 9.86 & 2.82 \\
$00-' 04$ & 4.19 & 6.26 & 1.64 \\
$90-' 98$ & 4.02 & 9.23 & 2.59 \\
$99-' 04$ & 3.01 & 7.80 & 2.18 \\
$71-' 04$ & 5.41 & 6.88 & 2.63
\end{tabular}

A more detailed analysis of labor productivity can be made by looking at growth rates of labor productivity by sub-sectors of both Manufacturing and Service industries as presented in Table A-1 and A-2 in Appendix. Within Manufacturing, we observe a large difference in growth rates of labor productivity ranging from Telecommunication equipment(17.22\%) to Aircraft and Spacecraft $(-24.58 \%)$. In general, export-oriented manufacturing industries such as Electrical machinery and apparatus $(13 \%$ range) and Chemicals, Basic metals (10\% range) have been leader industries in improving labor productivity.

In Service industries, the intra-industry difference of labor productivity growth is even larger than in Manufacturing. Gas Supply (28.24\%) and Water transport (14.32\%) have been leader industries because most of them have been public enterprises with rising demand for social overhead capital. On the other hand, Health and social work (-5.78 \%), Imputation of owner occupied rents (-5.72\%) and Other real estate activities (-4.72\%) have been on the lower end of the labor productivity growth.

\subsection{Gross Output Growth Accounting and TFP Growth}

The growth rate of economy-wide TFP has been estimated as -0.52 percent. The growth rates of TFP in Manufacturing and Service are estimated as 0.79 percent and -1.07 percent respectively throughout the entire period of 19712004 as shown in Table 4. Also the economy-wide TFP growth rate during the pre-crisis period (1990-1998) has been estimated as -0.65 percent. And the growth rate during the post-crisis period (1999-2004) has been estimated as 0.08 percent. 


\section{(1) The Level of TFP Growth and its Trend by Sector}

The growth rates of TFP by sector are shown in Figure 3. Throughout the entire period 1971-2004, Korean economy experienced about 2 break-points: mid-1970s which was the first oil shock and in 1997 which was the financial crisis. The difference between two break points can be summarized as follows. During the second half of 1970's, the growth rate of gross output was not low, but the growth rates of inputs such as capital(2.66\%), labor(1.13\%), energy $(1.20 \%)$, intermediate goods(5.02\%) especially, were relatively higher. Therefore, the growth rates of TFP have been estimated as negative. In case of late 1990's the negative growth of TFP has been resulted from the shrink of gross output rooted from economic crisis.

In addition we observe that the estimated TFP growth rates in Manufacturing are in general greater than in Service. It maybe due to the fact that innovation processes such as product innovation or process innovation are more sensitive and stronger in manufacturing than in service. Also the R\&D investment for innovation is in general more intensive in manufacturing than in service. So the growth rates of TFP in Manufacturing seem to be greater than in Service.

After the economic crisis in 1997-1998, the economy-wide growth rate of gross output has been recovered, at the same time the growth rates of input factors such as capital and service have also been reduced from those during the pre-crisis period. Accordingly, the growth rate of TFP during the post-crisis period has been relatively higher than that during the pre-crisis period. Secondly the contributions of TFP to economy-wide gross output growth during the entire period of 1971-2004 are -6.7 percent, and 7.7 percent in Manufacturing, and 15.0 percent in Service. Then we can examine the relative contribution ratio of the input factors to the output growth. The relative contribution ratios to output growth during the entire period are in order of intermediate goods (57.2 percent), capital (10.9 percent), energy (10.8 percent), service (8.9 percent), labor (4.5 percent) in Manufacturing. So the innovation or the role of intermediate goods for enhancing productivity is more important in Manufacturing than in Service. And the contribution ratio of TFP to Manufacturing output growth (7.7 percent) is of rather insignificant magnitude. On the other hand, in Service the contribution are in order of capital (39.5 percent), service (24.5 percent), intermediate goods (24.5 percent), labor (20.7 percent), energy (5.8 percent). Hence we can see the input's role for enhancing productivity is different between Manufacturing and Service. 
Figure 3 The growth rates of TFP (\%)
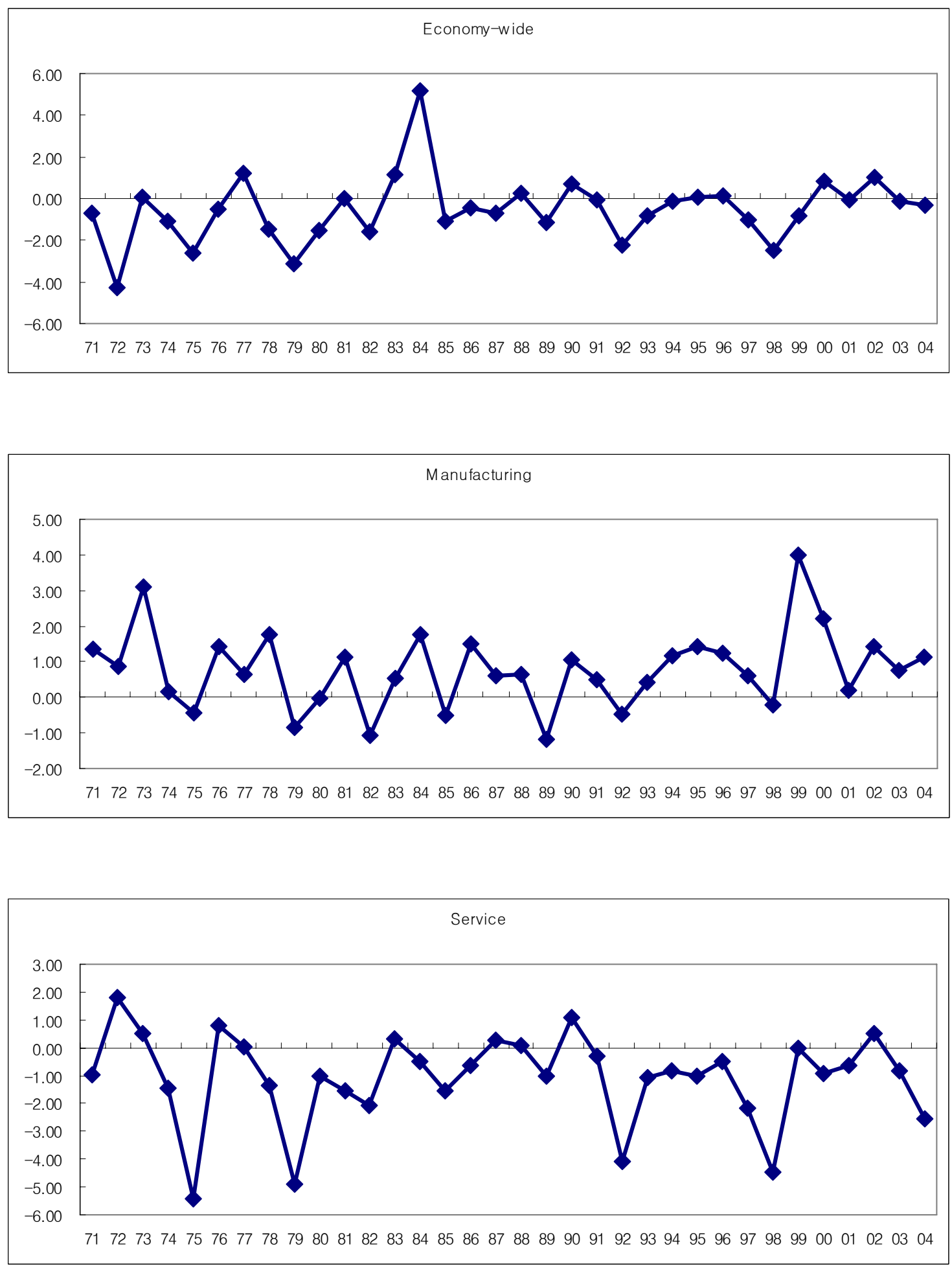
Thirdly the total factor productivity growth in gross output growth accounting is lower than that without quality adjustment in input data. The quality of labor has affected the growth of output about 1.7 percent in Manufacturing and 3.8 percent in Service during the entire period, Also the quantity of labor has affected the growth of output by about 2.8 percent in Manufacturing and about 16.9 percent in Service during the entire period. Thus the labor input in Service has influenced output growth both in quantity and quality of labor than that in Manufacturing. The quantity of labor input in Manufacturing has been reduced during the pre-crisis period. It reflects a drastic structural adjustment in Korea's labor market after the crisis of 1997-1998. As a consequence, the contribution rate of labor to output growth has become negative in Manufacturing before the crisis. In Service, Post and telecommunication which is related strongly with IT technology has recorded a relatively higher growth rate (6.09 percent) of TFP among service sectors.

On the one hand the sectors which were based on IT technology such as i) Telecommunication equipment(3.04 percent), ii) Other electrical machinery and apparatus(2.13 percent), iii) Office, accounting and computing machinery (1.76 percent) in Manufacturing, have shown higher growth rate of TFP during the entire period (1971-2004). But the labor intensive sectors such as i) Publishing (-0.09 percent), ii) Printing and reproduction (-0.37 percent), iii) Wearing apparel, dressing and dying of fur (-0.44 percent) have shown negative growth rates of total factor productivity.

In Service, Post and telecommunication which is related strongly with IT technology has recorded a relatively higher growth rate (6.09 percent) of TFP among service sectors. But the social and private sectors such as i) Other service activities (-10.67 percent), ii) Health and social work (-5.49 percent), iii) Public admin and defense (-1.70 percent), iv) Private households with employed persons (-1.00 percent) have shown negative growth rates of TFP. Therefore, we can see that the leading sectors for enhancing productivity growth are related with IT sectors. Korean economy has heavily invested in IT sectors on a full scale since 1995 as shown in Table 5 and recently analyzed in Ha and Pyo (2004). 
Table 4 Gross Output Growth Accounting and TFP growth

\begin{tabular}{|c|c|c|c|c|c|c|c|c|c|}
\hline \multirow[b]{3}{*}{ Period } & \multirow{3}{*}{$\begin{array}{l}\text { Gross } \\
\text { output }\end{array}$} & \multirow{3}{*}{$\begin{array}{l}\text { Capital } \\
\text { input }\end{array}$} & \multicolumn{3}{|c|}{ Economy-wide } & \multicolumn{4}{|c|}{ <unit: log growth rates $(\%)>$} \\
\hline & & & \multicolumn{3}{|c|}{ Labor input } & \multirow{2}{*}{$\begin{array}{l}\text { Energy } \\
\text { input }\end{array}$} & \multirow{2}{*}{$\begin{array}{l}\text { Intermediate } \\
\text { input }\end{array}$} & \multirow{2}{*}{$\begin{array}{c}\text { Service } \\
\text { input }\end{array}$} & \multirow[b]{2}{*}{ TFP } \\
\hline & & & $\begin{array}{l}\text { Total } \\
\text { labor }\end{array}$ & $\begin{array}{c}\text { Quantity } \\
\text { labor }\end{array}$ & $\begin{array}{l}\text { Quality } \\
\text { labor }\end{array}$ & & & & \\
\hline 71-'79 & 9.44 & 2.65 & 1.15 & 0.70 & 0.45 & 1.12 & 4.90 & 1.02 & -1.39 \\
\hline 80-'89 & 8.36 & 2.52 & -0.03 & -0.06 & 0.02 & 0.69 & 4.28 & 0.89 & 0.01 \\
\hline 90-'99 & 6.53 & 2.22 & 0.93 & 0.67 & 0.27 & 0.43 & 1.97 & 1.65 & -0.67 \\
\hline 00-'04 & 6.46 & 1.22 & 0.65 & 0.45 & 0.20 & 0.33 & 2.60 & 1.40 & 0.26 \\
\hline 90-'98 & 5.95 & 2.33 & 0.72 & 0.42 & 0.30 & 0.38 & 1.57 & 1.59 & -0.65 \\
\hline 99-'04 & 7.35 & 1.22 & 1.02 & 0.86 & 0.16 & 0.41 & 3.10 & 1.52 & 0.08 \\
\hline \multirow[t]{2}{*}{ 71-'04 } & 7.83 & 2.28 & 0.66 & 0.43 & 0.23 & 0.67 & 3.51 & 1.22 & -0.52 \\
\hline & \multicolumn{9}{|c|}{ Contribution to output growth } \\
\hline $71-79$ & 100.0 & 28.1 & 12.2 & 7.4 & 4.7 & 11.9 & 51.9 & 10.8 & -14.8 \\
\hline 80-'89 & 100.0 & 30.2 & -0.4 & -0.7 & 0.3 & 8.3 & 51.2 & 10.7 & 0.1 \\
\hline 90-'99 & 100.0 & 34.0 & 14.3 & 10.2 & 4.1 & 6.6 & 30.1 & 25.2 & -10.2 \\
\hline 00-'04 & 100.0 & 18.9 & 10.1 & 6.9 & 3.2 & 5.1 & 40.3 & 21.6 & 4.0 \\
\hline 90-'98 & 100.0 & 39.3 & 12.1 & 7.0 & 5.1 & 6.5 & 26.4 & 26.8 & -10.9 \\
\hline 99-'04 & 100.0 & 16.6 & 13.9 & 11.7 & 2.2 & 5.6 & 42.1 & 20.7 & 1.0 \\
\hline 71-'04 & 100.0 & 29.1 & 8.5 & 5.5 & 3.0 & 8.6 & 44.9 & 15.6 & -6.7 \\
\hline
\end{tabular}

\section{Manufacturing}

\begin{tabular}{|c|c|c|c|c|c|c|c|c|c|}
\hline \multirow[b]{2}{*}{ Period } & \multirow[b]{2}{*}{$\begin{array}{l}\text { Gross } \\
\text { output }\end{array}$} & \multirow{2}{*}{$\begin{array}{l}\text { Capital } \\
\text { input }\end{array}$} & \multicolumn{3}{|c|}{ Labor input } & \multirow[b]{2}{*}{$\begin{array}{c}\text { Energy } \\
\text { input }\end{array}$} & \multirow{2}{*}{$\begin{array}{l}\text { Intermediate } \\
\text { input }\end{array}$} & \multirow[b]{2}{*}{$\begin{array}{c}\text { Service } \\
\text { input }\end{array}$} & \multirow[b]{2}{*}{ TFP } \\
\hline & & & $\begin{array}{l}\text { Total } \\
\text { labor }\end{array}$ & $\begin{array}{c}\text { Quantity } \\
\text { labor }\end{array}$ & $\begin{array}{l}\text { Quality } \\
\text { labor }\end{array}$ & & & & \\
\hline 71-'79 & 15.14 & 1.42 & 1.11 & 0.94 & 0.16 & 2.00 & 8.78 & 0.94 & 0.89 \\
\hline 80-'89 & 10.27 & 1.29 & 0.54 & 0.39 & 0.14 & 1.03 & 6.44 & 0.64 & 0.34 \\
\hline 90-'99 & 7.02 & 1.00 & -0.12 & -0.37 & 0.25 & 0.76 & 3.35 & 1.07 & 0.97 \\
\hline 00-'04 & 8.16 & 0.53 & 0.32 & 0.21 & 0.11 & 0.40 & 4.66 & 1.12 & 1.15 \\
\hline 90-'98 & 5.65 & 1.08 & -0.18 & -0.46 & 0.28 & 0.70 & 2.49 & 0.93 & 0.64 \\
\hline 99-'04 & 10.03 & 0.48 & 0.33 & 0.24 & 0.09 & 0.54 & 5.73 & 1.32 & 1.62 \\
\hline \multirow[t]{2}{*}{ 71-'04 } & 10.29 & 1.13 & 0.46 & 0.29 & 0.18 & 1.11 & 5.89 & 0.92 & 0.79 \\
\hline & \multicolumn{9}{|c|}{ Contribution to output growth } \\
\hline $71-79$ & 100.0 & 9.4 & 7.3 & 6.2 & 1.1 & 13.2 & 58.0 & 6.2 & 5.9 \\
\hline $80-' 89$ & 100.0 & 12.5 & 5.2 & 3.8 & 1.4 & 10.1 & 62.7 & 6.2 & 3.3 \\
\hline 90-'99 & 100.0 & 14.2 & -1.7 & -5.3 & 3.6 & 10.8 & 47.7 & 15.2 & 13.8 \\
\hline
\end{tabular}




\begin{tabular}{cccccccccc}
$00-' 04$ & 100.0 & 6.5 & 3.9 & 2.5 & 1.4 & 4.8 & 57.0 & 13.7 & 14.0 \\
$90-' 98$ & 100.0 & 19.1 & -3.1 & -8.2 & 5.0 & 12.3 & 44.0 & 16.4 & 11.3 \\
$99-' 04$ & 100.0 & 4.8 & 3.3 & 2.4 & 0.9 & 5.4 & 57.1 & 13.2 & 16.2 \\
\hline $71-' 04$ & 100.0 & 10.9 & 4.5 & 2.8 & 1.7 & 10.8 & 57.2 & 8.9 & 7.7 \\
\hline
\end{tabular}

\section{Service}

\begin{tabular}{|c|c|c|c|c|c|c|c|c|c|}
\hline \multirow[b]{2}{*}{ Period } & \multirow{2}{*}{$\begin{array}{l}\text { Gross } \\
\text { output }\end{array}$} & \multirow{2}{*}{$\begin{array}{l}\text { Capital } \\
\text { input }\end{array}$} & \multicolumn{3}{|c|}{ Labor input } & \multirow{2}{*}{$\begin{array}{l}\text { Energy } \\
\text { input }\end{array}$} & \multirow{2}{*}{$\begin{array}{c}\text { Intermediate } \\
\text { input }\end{array}$} & \multirow{2}{*}{$\begin{array}{c}\text { Service } \\
\text { input }\end{array}$} & \multirow[b]{2}{*}{ TFP } \\
\hline & & & $\begin{array}{l}\text { Total } \\
\text { labor }\end{array}$ & $\begin{array}{l}\text { Quantity } \\
\text { labor }\end{array}$ & $\begin{array}{l}\text { Quality } \\
\text { labor }\end{array}$ & & & & \\
\hline 71-'79 & 7.98 & 2.39 & 1.89 & 1.48 & 0.41 & 0.73 & 2.65 & 1.55 & -1.22 \\
\hline 80-'89 & 7.92 & 3.38 & 1.20 & 1.10 & 0.09 & 0.44 & 2.31 & 1.36 & -0.77 \\
\hline 90-'99 & 6.66 & 3.18 & 1.46 & 1.17 & 0.29 & 0.17 & 0.84 & 2.34 & -1.33 \\
\hline 00-'04 & 5.17 & 1.85 & 1.35 & 1.00 & 0.35 & 0.29 & 0.86 & 1.73 & -0.89 \\
\hline 90-'98 & 6.74 & 3.29 & 1.60 & 1.27 & 0.33 & 0.14 & 0.82 & 2.36 & -1.48 \\
\hline 99-'04 & 5.30 & 1.90 & 1.16 & 0.88 & 0.28 & 0.31 & 0.88 & 1.80 & -0.75 \\
\hline \multirow[t]{2}{*}{ 71-'04 } & 7.16 & 2.83 & 1.48 & 1.21 & 0.27 & 0.42 & 1.75 & 1.75 & -1.07 \\
\hline & \multicolumn{9}{|c|}{ Contribution to output growth } \\
\hline 71-'79 & 100.0 & 29.9 & 23.7 & 18.5 & 5.1 & 9.1 & 33.2 & 19.4 & -15.3 \\
\hline $80-' 89$ & 100.0 & 42.7 & 15.1 & 13.9 & 1.2 & 5.5 & 29.2 & 17.2 & -9.7 \\
\hline 90-'99 & 100.0 & 47.7 & 22.0 & 17.6 & 4.3 & 2.6 & 12.6 & 35.1 & -20.0 \\
\hline 00-'04 & 100.0 & 35.8 & 26.0 & 19.2 & 6.8 & 5.5 & 16.6 & 33.4 & -17.3 \\
\hline 90-'98 & 100.0 & 48.8 & 23.8 & 18.9 & 4.9 & 2.1 & 12.2 & 35.0 & -22.0 \\
\hline 99-'04 & 100.0 & 35.9 & 21.8 & 16.6 & 5.2 & 5.9 & 16.6 & 33.9 & -14.1 \\
\hline 71-'04 & 100.0 & 39.5 & 20.7 & 16.9 & 3.8 & 5.8 & 24.5 & 24.5 & -15.0 \\
\hline
\end{tabular}

Table 5 The Investment in IT sector

(in 2000 constant prices)

\begin{tabular}{ccc}
\hline Year & IT Investment(billion won) & Growth (\%) \\
\hline 1995 & $15,125.7$ & - \\
1996 & $17,916.0$ & 18.4 \\
1997 & $19,122.0$ & 6.7 \\
1998 & $17,099.2$ & -10.6 \\
1999 & $23,716.0$ & 38.7 \\
2000 & $32,190.9$ & 35.7 \\
2001 & $31,502.0$ & -2.1
\end{tabular}


Source: Bank of Korea (http://ecos.bok.or.kr)

\subsection{Cumulative Contribution of Sectors to TFP growth}

Following Fukao et. al,(2006), we can examine the sectoral contribution of TFP growth and identify what are the core sectors for enhancing productivity. As shown in Figure 4, the weight of gross output of the sectors with positive Economy-wide TFP growth is about $57 \%$ while the weight with negative TFP growth is about $43 \%$ during the entire period of 1971-2004.

We can identify sectors that have contributed to the growth of economy-wide TFP positively. Leading sectors in this group include Electrical supply and Post and Telecommunications, and Financial intermediation in Service and Chemicals and Basic metals in Manufacturing among others. We also identify sectors with negative contribution to Economy-wide TFP growth such as Agriculture, Hotels and Restaurants, Imputation of owner-occupied housing and Other service activities etc.

As shown in Figure 4, the weight of gross output of the sectors with positive TFP growth in Manufacturing is $90.7 \%$ while the weight with negative TFP growth is $9.3 \%$ during the period of 1971-2004. The sub-sectors with positive TFP growth are basic metals, chemicals, machinery, textiles, rubber and plastic, fabricated metal, wood, other non metallic mineral, motor vehicles and trailers as non IT sectors, and electronic valves and tubes, office, accounting and computing machinery, telecommunications, radio and TV receivers as IT sectors. The sub-sectors with negative TFP growth are Publishing, Printing and reproduction, Wearing apparel, Aircraft and spacecraft etc.

On the other hand, we can look at Service industry separately. As shown in Figure 4, the weight of gross output of the sectors with positive TFP growth in Service is only about $30 \%$ while the weight with negative TFP growth is $70 \%$ during the period of 1971-2004. The group of service industries with positive TFP growth includes Financial intermediation, Post and communication, Inland Transport, Insurance and pension, Water Transport etc. The group with negative TFP growth includes Hotels and Restaurants, Imputation of owner-occupied housing, Other service activities and Wholesale trade etc. 
Figure 4 Cumulative Contribution of sectors to TFP Growth (1971-2004) Economy-wide

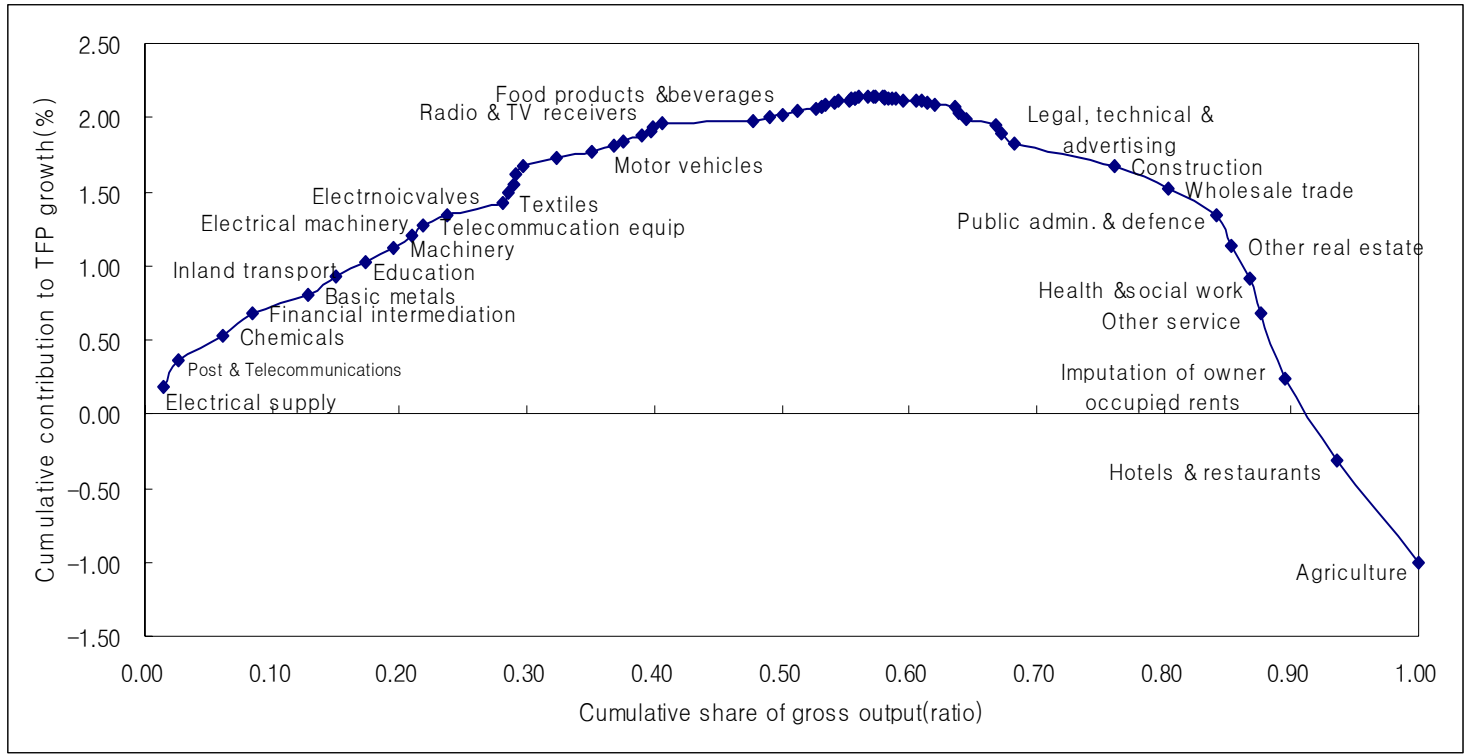

\section{Manufacturing}

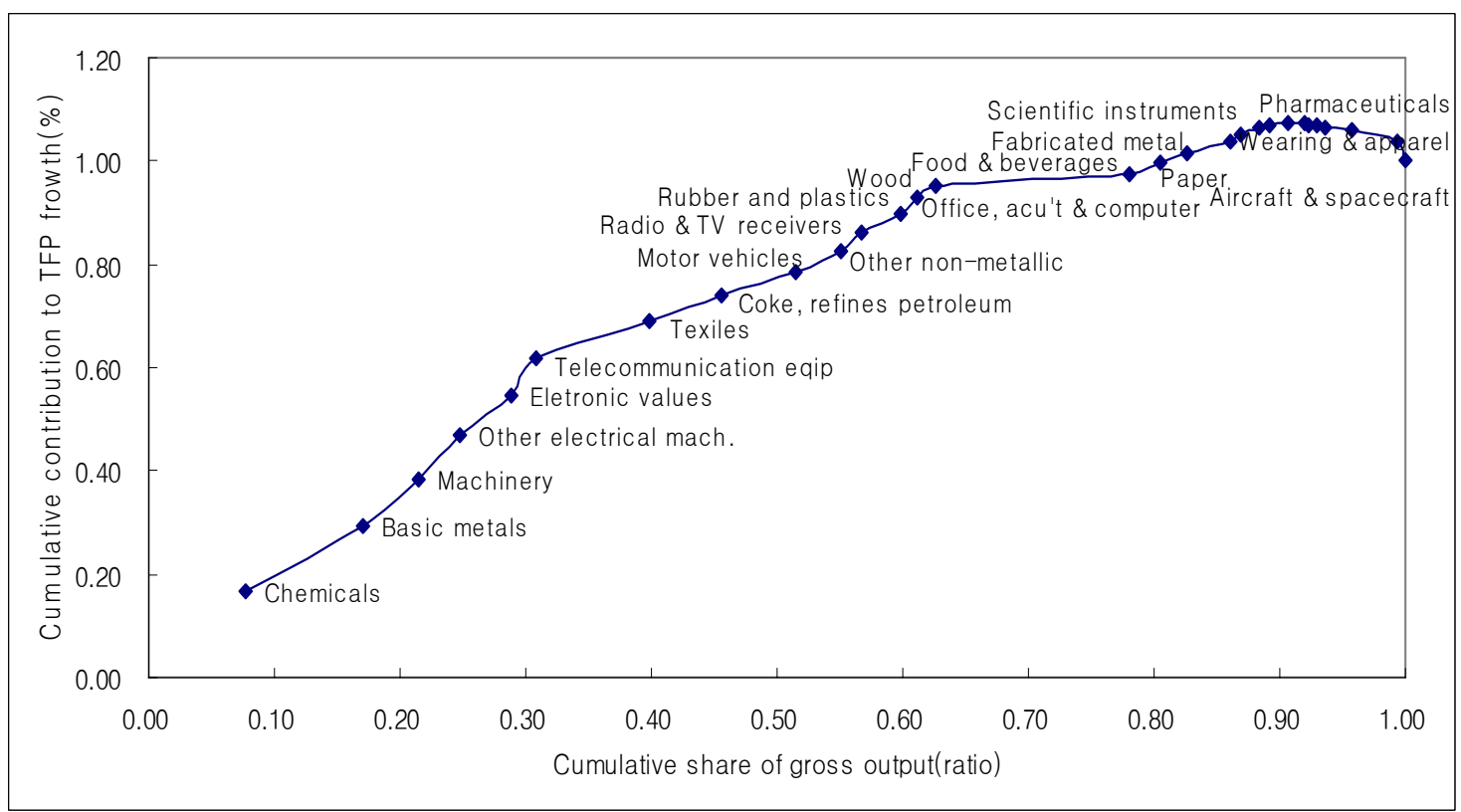




\section{Service}

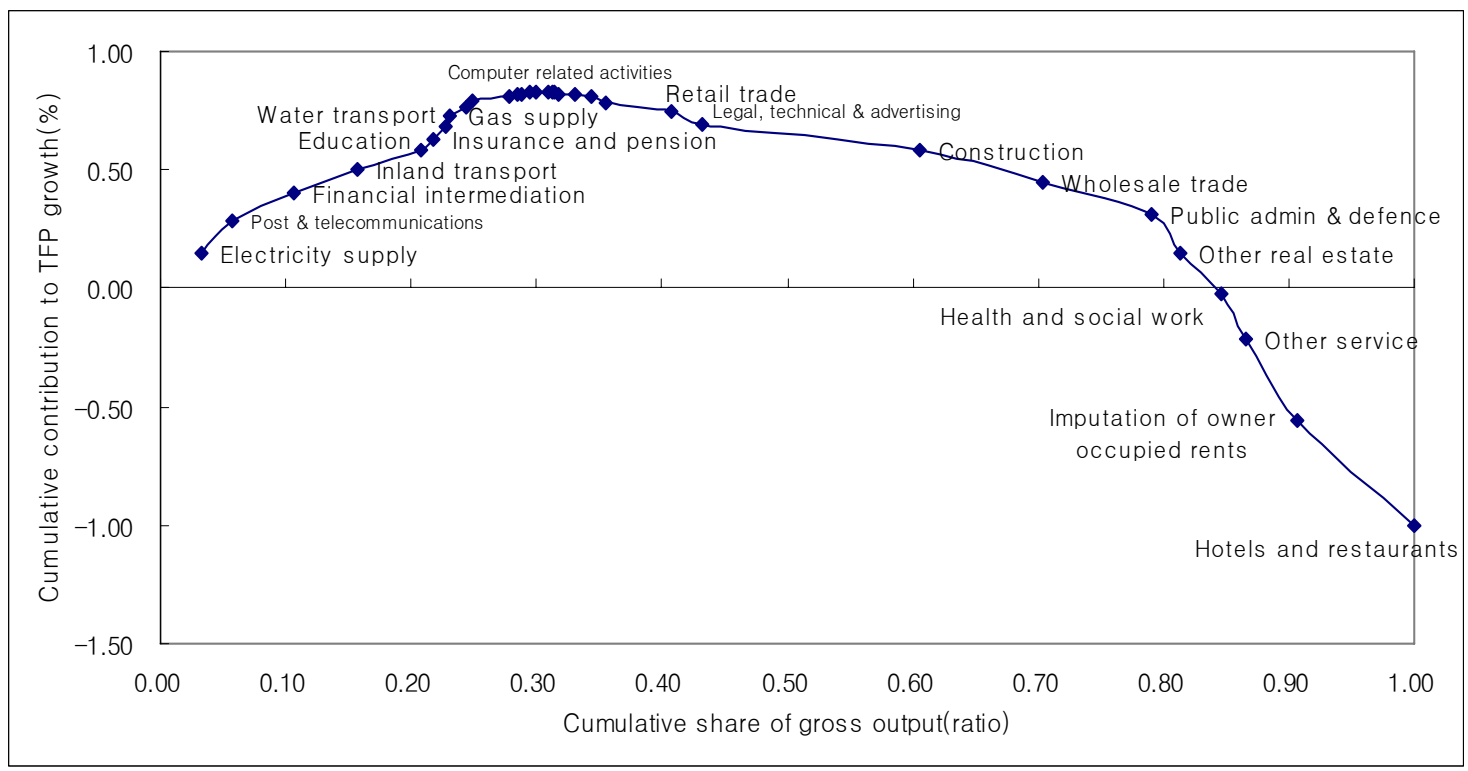

\subsection{Relations of TFP growth with Labor Productivity and Output Growth}

In order to identify the relation between labor productivity growth and TFP growth, we can divide sectors into 4 groups by the average growth rates in Manufacturing and Service. The relations of TFP with labor productivity and output growth can be further examined by looking at the scatter diagrams such as Figure 5 and 6 . A visual inspection tells us that TFP growth is positively correlated with both labor productivity growth and output growth and TFP-LP relation is stronger than TFP -Output relation.

In Table 6, we have summarized two simple regression results where TFP Growth rate is regressed upon LP and output growth rate. We are adopting implicit hypotheses that higher LP and output growth induces TFP growth through enhanced human capital and economies of scale. In both regressions, the coefficients of LP growth and Output Growth are significant. The TFP-LP regression seems more significant than TFP-Output regression. 
Figure 5 Plotting between TFP Growth and Sectoral Labor Productivity Growth (1971-2004, \%)

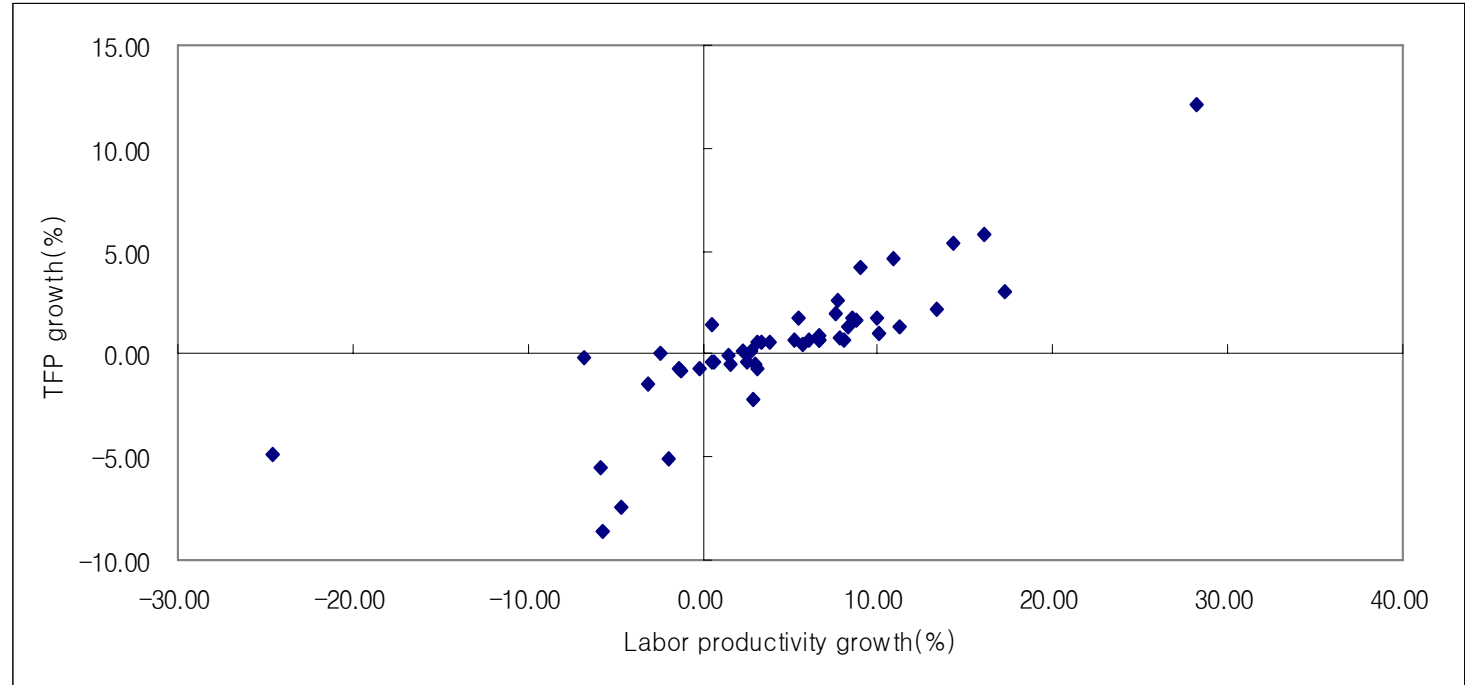

Figure 6 Plotting between TFP Growth and Sectoral Gross output Growth (1971-2004, \%)

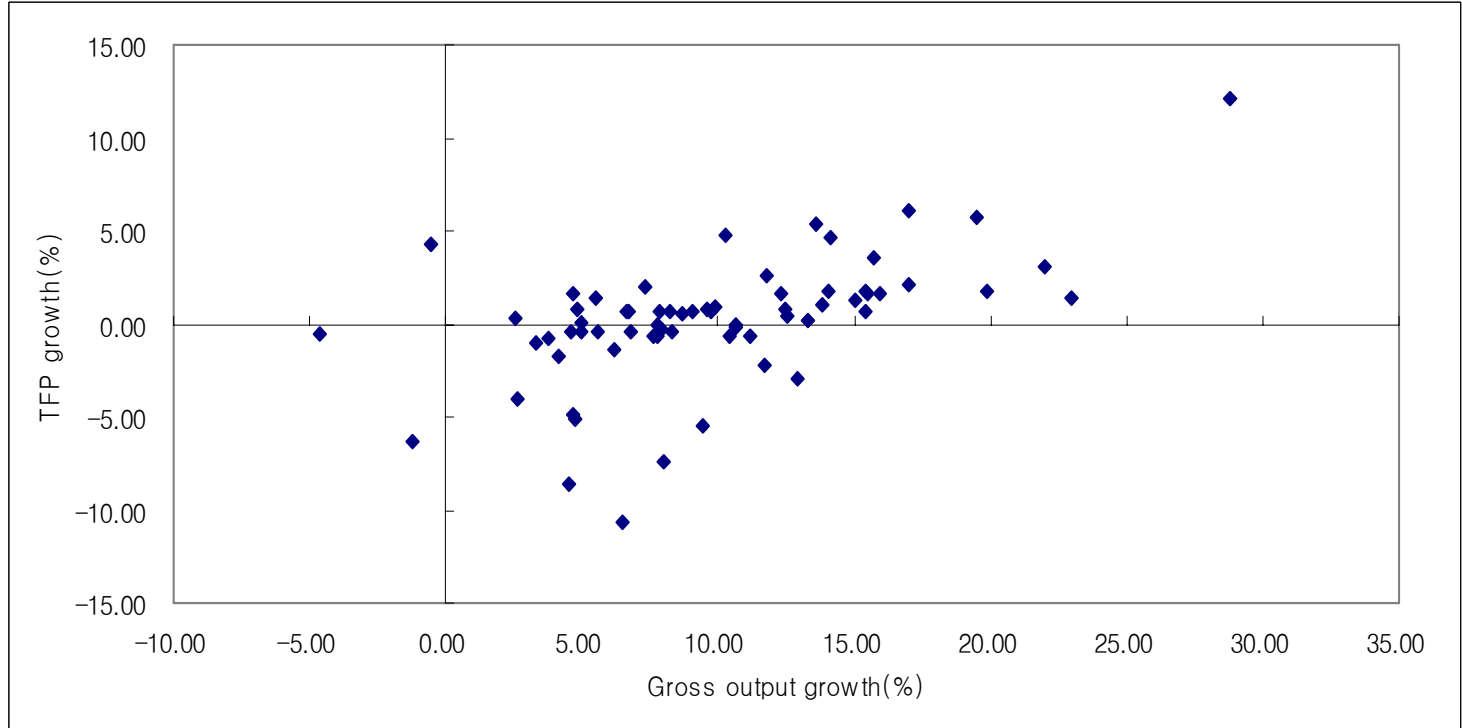




\section{Regression of TFP Growth on Labor Productivity Growth}

Model: $\log ($ TFPt/TFPt-1) $=\alpha+\beta \log ($ LPt/LPt-1) $+\gamma$

$\log ($ TFPt/TFPt-1) $=$ Sectoral average TFP growth rate during 1971-2004, $\log (\mathrm{LPt} / \mathrm{LPt}-1) \quad=$ Sectoral average labor productivity growth rate during 1971-2004

Number of sectors: 49 sectors (except some sectors for data insufficiency)

\begin{tabular}{lcccc}
\hline Dependent var. & B & S.E & DW & $\operatorname{adjR}^{2}$ \\
\hline TFP Growth Rate & $0.345^{\star \star *}$ & 0.034 & 1.711 & 0.677 \\
\hline
\end{tabular}

${ }^{* * *}: \operatorname{Pr}>\mathrm{t}$ is $1 \%,{ }^{* *}: \operatorname{Pr}>\mathrm{t}$ is $5 \%,{ }^{*}: \operatorname{Pr}>\mathrm{t}$ is $10 \%$

\section{Regression of TFP Growth on Gross Output Growth}

Model: $\log ($ TFPt/TFPt-1 $)=\alpha+\beta \log ($ GOt/GOt-1 $)+\gamma$

log (TFPt/TFPt-1) = Sectoral average TFP growth during 1971-2004,

$\log (\mathrm{GOt} / \mathrm{GOt}-1)$ = Sectoral average Gross output growth rate during 19712004

Number of sectors: 66 sectors(except some sectors for data insufficiency)

\begin{tabular}{lcccc}
\hline Dependent var. & B & S.E & DW & $\operatorname{adjR}^{2}$ \\
\hline TFP Growth rate & $0.326^{* * *}$ & 0.060 & 1.473 & 0.301 \\
\hline
\end{tabular}

${ }^{* * *}: \operatorname{Pr}>t$ is $1 \%,{ }^{* *}: \operatorname{Pr}>t$ is $5 \%,{ }^{*}: \operatorname{Pr}>t$ is $10 \%$ 


\section{A Linear Rank Test of Independence}

In addition to regression analysis, we have used a type of distribution-free linear rank statistic, a generalization of the Mann-Whitney-Wilcoxon statistic for two Independent samples following Baily, Hulten and Campbell (1992) and Hogg and Craig (1978) and Choi (2003) and Neter et al.(1996).

Let $\left(X_{1}, Y_{1}\right),\left(X_{2}, Y_{2}\right), \ldots,\left(X_{n}, Y_{n}\right)$ be a random sample from a bivariate distribution of the continuous type. Let $R_{i}$ be the rank of $X_{i}$ among $X_{1}, X_{2}, \ldots, X_{n}$ and $Q_{i}$ be the rank of $Y_{i}$ among $Y_{1}, Y_{2}, \ldots, Y_{n}$. If $\mathrm{X}$ and $\mathrm{Y}$ have a large positive correlation coefficient, we would anticipate that $R_{i}$ and $Q_{i}$ would tend to be large or small together. In particular, the correlation coefficient of $\left(R_{1}, Q_{1}\right),\left(R_{2}, Q_{2}\right), \ldots,\left(R_{n}, Q_{n}\right)$, namely the Spearman rank correlation coefficient :

$$
r_{s}=\frac{\sum_{i=1}^{n}\left(R_{i}-\bar{R}\right)\left(Q_{i}-\bar{Q}\right)}{\sqrt{\sum_{i=1}^{n}\left(R_{i}-\bar{R}\right)^{2} \sum_{i=1}^{n}\left(Q_{i}-\bar{Q}\right)^{2}}}
$$

would tend to be large. Since $R_{1}, R_{2}, \ldots, R_{n}$ and $Q_{1}, Q_{2}, \ldots, Q_{n}$ are permutations of $1,2, \ldots, \mathrm{n}$, this correlation coefficient can be shown to equal :

$$
r_{s}=1-\frac{6 \sum_{i=1}^{n}\left(R_{i}-Q_{i}\right)^{2}}{n\left(n^{2}-1\right)}
$$

The mean and the variance of $r_{s}$ under $H_{0}$ is derived as:

$$
\mu_{s}=0, \quad \sigma_{s}^{2}=\frac{1}{\sqrt{n-1}}
$$

As shown in Table 7, the computed linear rank statistics reject the null hypotheses that TFP growth is stochastically independent of LP growth and that TFP growth is stochastically independent of output growth at the $1 \%$ significance level. 
Table 7 Test Statistics for Testing the Stochastic Independence

$$
\begin{aligned}
& r_{s}(T F P-L P)=0.8864 \\
& r_{s}(T F P-G O)=0.6150 \\
& H_{0}: \rho=0 \quad H_{1}: \rho \neq 0 \\
& \operatorname{Pr}_{H_{0}}\left(r_{s}\right) \geq r_{s}(n ; \alpha)=\alpha \\
& \frac{r-E_{H_{0}}\left(r_{s}\right)}{\sqrt{\operatorname{Var}_{H_{0}}\left(r_{s}\right)}}=r_{s} \sqrt{n-1} \rightarrow N(0,1) \\
& Z(T F P-L P)=0.8864 \times \sqrt{(49-1)}=6.141 \\
& Z(T F P-G O)=0.6150 \times \sqrt{(49-1)}=4.261
\end{aligned}
$$

\section{Conclusion}

The purpose of this paper is to explain how the database of Korea has been constructed for estimating productivities by industry in KLEMS model and how we have estimated 72-industry level labor productivity and TFP. We have also conducted a gross output growth accounting. Throughout the entire period of 1971-2004, the economy-wide labor productivity has grown at the average rate of 5.41 percent but with the sectoral difference between Manufacturing $(6.88 \%)$ and Service $(2.63 \%)$. The difference did not shrink but rather has expanded as the process of industrialization of the Korean economy continued. For example, the difference in the 1990 's $(9.86 \%$ vs. $2.82 \%$ ) has been more than doubled since 1970 's ( $4.15 \%$ vs. $1.77 \%$ ). The observed difference in both levels and growth rates of labor productivity between Manufacturing and Service can signal the difference in the degree of foreign competition, the proportion of tradable goods and non-tradable goods and services and the degree of domestic competition due to historically different regulatory environments.

The growth rate of economy-wide TFP has been estimated as -0.52 percent. The growth rates of TFP in Manufacturing and Service are estimated as 0.79 percent and -1.07 percent respectively throughout the entire period of 19712004. Korean economy experienced two major break-points: in 1974 which was 
the first oil shock and in 1997 which was the financial crisis. The difference between two break points can be summarized as follows. During the second half of 1970's, the growth rate of gross output was not low, but the growth rates of inputs such as capital(2.66\%), labor(1.13\%), energy(1.20\%), intermediate goods $(5.02 \%)$ especially, were relatively higher. Therefore, the growth rates of TFP have been estimated as negative. In case of late 1990's the negative growth of TFP has been resulted from the shrinkage of gross output rooted from economic crisis.

In addition we observe that the estimated TFP growth rates in Manufacturing are in general greater than in Service. It maybe due to the fact that an innovation process such as product innovation or process innovation is more sensitive and stronger in Manufacturing than in Service. Also the R\&D investment for innovation is in general more intensive in Manufacturing than in Service. So the growth rates of TFP in Manufacturing seem to be greater than in Service.

We can identify sectors that have contributed to the growth of economy-wide TFP positively by decomposing relative contribution of each sector to total TFP growth (Y-axis) with each sector's relative weight of output (X-axis). Leading sectors in this group include Electrical supply, Post and Telecommunications and Financial Intermediation in Service and Chemicals and Basic Metals in Manufacturing among others. We also identify sectors with negative contribution to Economy-wide TFP growth such as Agriculture, Hotels and Restaurants, Imputation of owner-occupied housing and Other service activities etc.

The relations of TFP with labor productivity and output growth can be examined by looking at the scatter diagrams and a regression analysis. A visual inspection tells us that TFP growth is positively correlated with both labor productivity growth and output growth and TFP-LP relation is stronger than TFP -Output relation. We have adopted an implicit hypothesis that higher LP and output growth induces TFP growth through enhanced human capital and economies of scale. In both regressions, the coefficients of LP growth and Output Growth are significant. The TFP-LP regression seems more significant than TFP-Output regression.

Productivities in an economy are not identical across industries, and productivity differences are also observed when compared with other economies. For example, most industries in Japan exhibit higher productivity in Manufacturing such as Electrical machinery, Motor and other transport vehicles, 
and Instruments industries resulting in higher productivity in the entire economy. However, total factor productivities of Korea in Construction, Petroleum products, Fabricated machinery, and Finance industries are higher than those of Japan. International comparison of productivity among industries will demonstrate a relative productivity of each industry, illustrating whether the way goods and services are produced is relatively efficient or not and referring to the appropriate policies for improvement such as competition, restriction, R\&D policies, and so on. Establishment of dataset with the same standards for productivity measurement will facilitate these inter-industry and international comparisons, and contribute to better understanding of economic growth.

\section{References}

[1] Baily, Martin Neil, Charles Hulten, and David Campbell " Productivity Dynamics in Manufacturing Plants," Brookings Papers on Economic Activity:Microeconomics, pp.187-249,1992

[2] Berndt, E. and L. Christensen, "The Translog Function and the Substitution of Equipment, Structures, and Labor in US Manufacturing, 1929-1968," Journal of Econometrics, Vol.1, pp.81-114, 1973

[3] Berndt, E. and L. Christensen, "Testing for the Existence of a Consistent Aggregate Index of Labor Input," American Economic Review, Vol.3, pp.391404, 1974

[4] Berndt, E. and D. Wood, "Technology, Prices, and the Derived Demand for Energy," Review of Economics and Statistics, Vol.57, pp.259-268, 1975

[5] Byoung Seon Choi, SungBaek Lee, Modern Statistics Using SAS, Sekyung Sa, 2003, in Korean

[6] Denny, M. and M. Fuss, "The Use of Approximation Analysis to Test for Separability and the Existence of Consistent Aggregates," American Economic Revew, vol.67, pp.404-418, 1977

[7] Harberger, Arnold C., "Perspectives on Capital and Technology in LessDeveloped Countries," in Contemporary Economic Analysis: Papers presented at the conference of the Association of University Teachers of Economics," Edited by Artis, Michael J. and Nobay, A. R., Croom Helm London, 1987

[8] Hogg and Craig, Introduction to Mathematical Statistics, Fourth edition, Collier Macmillan International Editions, 1978 
[9] Inklaar, Robert, Marcel P. Timmer and Bart van Art (2006), "Mind the Gap!: International Comparisons of Productivity in Services and Goods Production," unpublished manuscript

[10] Jorgenson, D.W., F. M. Gollop and B.M.Fraumeni, Productivity and US Economic Growth, Cambridge MA: Harvard University Press, 1987

[11] Jorgenson, D.W., Mun S. Ho, and Kevin J. Stiroh, "Growth of U.S. Industries and Investments in Information Technology and Higher Education," in Measuring Capital in the New Economy, edited by Carol Corrado, John Haltiwanger, and Daniel Sichel, Studies in Income and Wealth Vol. 65, National Bureau of Economic Research, 2005

[12] Kim Hyunjeong, "The Shift to the Service Economy; Causes and Effects", BOK Institute, Working Paper 254, May 2006

[13]Krugman, Paul, "The Myth of Asia's Miracle," Foreign affairs, November/December, 1994

[14] Kyoji Fukao, "Industry and firm level total factor productivity and economic growth in Japan", RIETI Workshop, July 2006,

[15] Kyoji Fukao, et al., "Estimation Procedures and TFP Analysis of the JIP Analysis of the JIP Database 2006 Provisional Version", Paper presented at RIETI Conference on Determinants of Total Factor Productivity and Japan's Potential Growth: An International Perspective, July 25, 2006

[16] Lau, Lawrence J. and Jong-II Kim, "The Sources of Growth of East Asian Newly Industrialized Countries," Journal of Japanese and International Economies, 1994.

[17] Lewis, W. William, The Power of Productivity: Wealth, Poverty, and the Threat to Global Stability, University of Chicago Press, 2004

[18] Neter John, Michael H.Kutner, Christopher J.Nachtsheim, and William Wasserman, "Applied Linear Statistical Models", Mc Graw Hill, 1996

[19] Pyo, Hak K., "Estimates of Capital Stock and Capital / Output Coefficients by Industries: Korea, 1953-1986", International Economic Journal, summer 1988

[20] Pyo, Hak K., "A Synthetic Estimate of National Wealth of Korea", 19531990, KDI Working Paper No.9212, Korea Development Institute, Seoul, 1992

[21] Pyo. Hak K, "Estimates of Fixed Reproducible Tangible Assets in the Republic of Korea, 1953-1996", KDI Working Paper No.9810, Korea Development Institute, Seoul, 1998 
[22] Pyo, Hak K., "Estimates of Capital Stocks by Industries and Types of Assets in Korea (1953-2000)", Journal of Korean Economic Analysis, Panel for Korean Economic Analysis and Korea Institute of Finance, Seoul 2003

[23] Pyo, Hak K., "Interdependecy in East Asia and the Post-Crisis Macroeconomic Adjustment in Korea", Seoul Journal of Economics, Volume 17 Number 1, Spring 2004

[24] Pyo Hak K. and Bongchan Ha, "A Test of Separability and Random Effects in Production Function with Decomposed IT Capital," Hitotsubashi Journal of Economics 48, 2007 (forthcoming)

[25] Pyo Hak K., Keun-Hee Rhee, and Bongchan Ha , "Growth Accounting, Productivity Analysis, and Purchasing Power Parity in Korea(1984-2000)", presented at the Fifth Workshop on the International Comparison of Productivity among Asian Countries, October, 2004, Tokyo, Japan, 2004

[26] Pyo Hak K. and Bongchan Ha, "Productivity Convergence and Investment Stagnation in East Asia," presented at CIRJE seminar, University of Tokyo, Japan, July 21, 2005

[27] Pyo Hak K., Keun-Hee Rhee, and Bongchan Ha , "Productivity Analysis by Industry in Korea and International Comparison through EU KLEMS Database:Data Structure", Paper presented at EU-KLEMS Workshop, May 7-9, 2006, Valencia

[28] Pyo Hak K., Investment Stagnation in East Asia and Policy Implications for Sustainable Growth, Working Paper 06-01,Korea Institute for International Economic Policy, Seoul

[29] Timmer, Marcel, "The Dynamics of Asian Manufacturing: A Comparative Perspective, 1963-1993", Eindhoven Centre for Innovation Studies, Dissertation Series, 1999

[30] Timmer, Marcel, "EU KLEMS Road map WP1," EU KLEMS webpage, October, 2005

[31] Young, Alwyn, "Lessons from the East Asian NICs : A Contrarian View," European Economic Review papers and proceedings, 1994

[32] Yuhn Ky-Hyang, "Functional Separability and the Existence of Consistent Aggregates in U.S. Manufacturing," International Economic Review, Vol.32, No.1, pp.229-250, 1991 


\section{Appendix}

Figure A-1 Growth Rates of Labor Productivity in Manufacturing (1971$04, \%)$

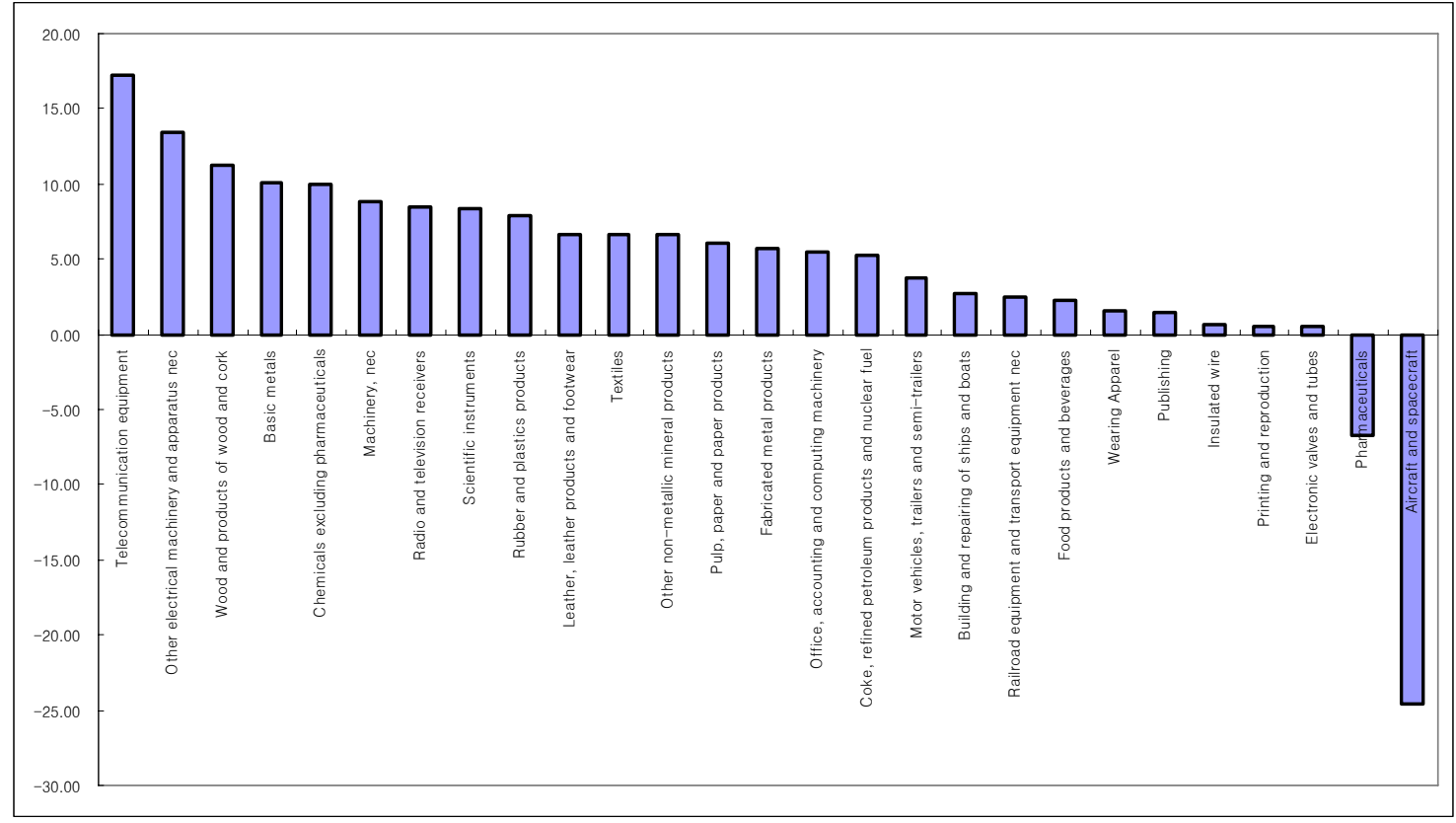

Figure A-2 Growth Rates of Labor Productivity in Service (1971-04, \%)

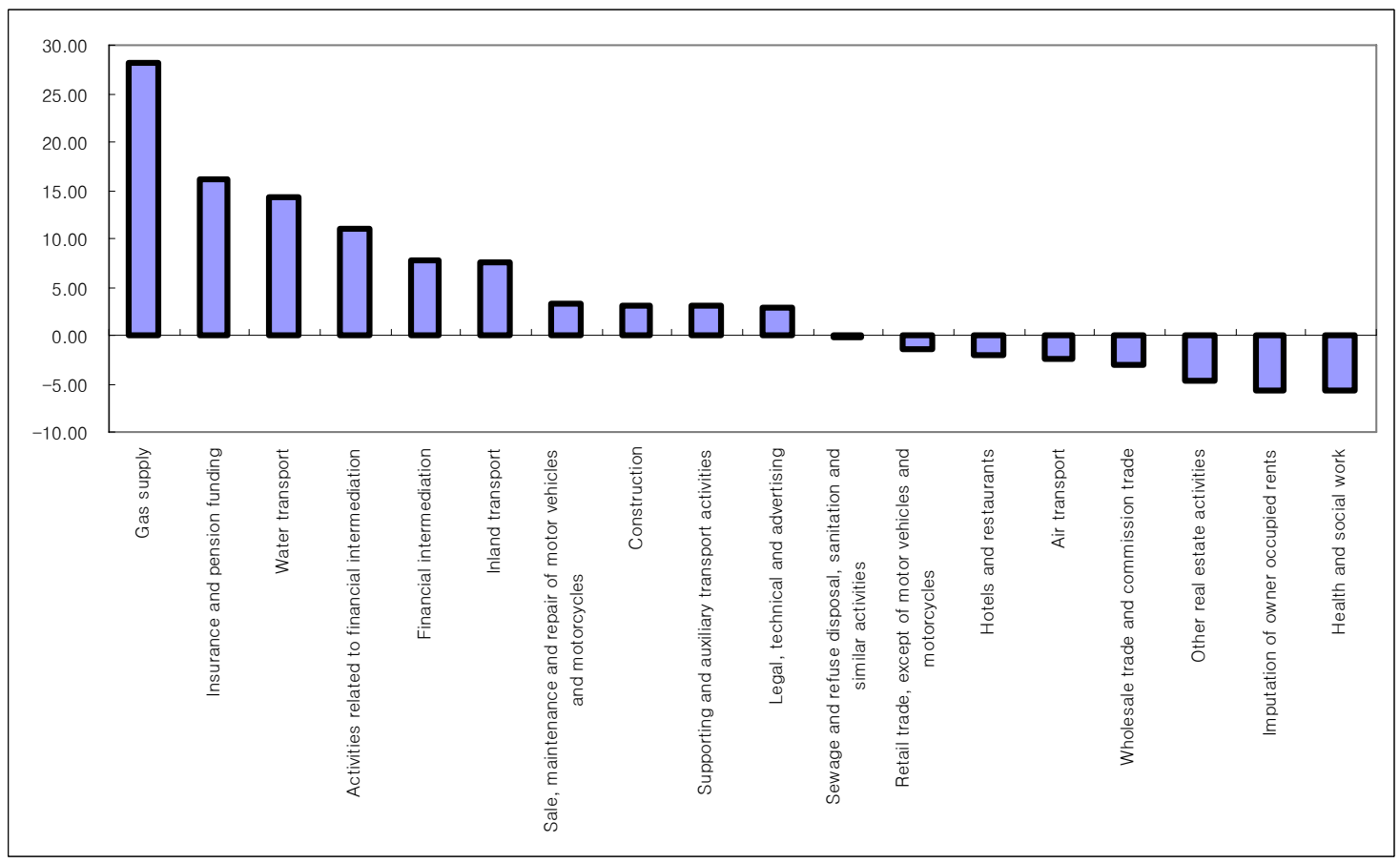


Table A-1 Sectoral TFP growth in manufacturing (\%)

\begin{tabular}{|c|c|c|c|c|c|c|c|}
\hline \multirow[t]{2}{*}{ Code } & \multirow[t]{2}{*}{ Industry } & \multirow[t]{2}{*}{$71-' 79$} & \multirow[t]{2}{*}{$80-' 89$} & \multirow[t]{2}{*}{$90-' 99$} & $\begin{array}{l}\text { Before } \\
\text { crisis }\end{array}$ & $\begin{array}{l}\text { After } \\
\text { crisis }\end{array}$ & \multirow[t]{2}{*}{ 71-'04 } \\
\hline & & & & & $90-' 98$ & 99-'04 & \\
\hline 9 & Food products and beverages & 0.44 & 0.14 & -0.12 & -0.10 & -0.08 & 0.12 \\
\hline 10 & Tobacco products & 1.39 & 1.23 & 1.05 & 1.35 & -1.94 & 0.75 \\
\hline 11 & Textiles & 1.84 & 0.23 & 0.43 & 0.09 & 0.33 & 0.64 \\
\hline 12 & Wearing Apparel & -0.31 & -0.57 & -0.98 & -1.62 & 1.34 & -0.44 \\
\hline 13 & Leather, leather products and footwear & 1.09 & -0.35 & 1.93 & 1.99 & -0.27 & 0.66 \\
\hline 14 & Wood and products of wood and cork & 3.20 & 0.37 & 1.05 & 1.23 & 0.31 & 1.34 \\
\hline 15 & Pulp, paper and paper products & 0.75 & 1.24 & 0.91 & 0.82 & -0.41 & 0.71 \\
\hline 16 & Publishing & -0.31 & 2.20 & -0.20 & -1.62 & -1.24 & -0.09 \\
\hline 17 & Printing and reproduction & 1.21 & -1.30 & -0.08 & 0.62 & -2.66 & -0.37 \\
\hline 18 & Coke, refined petroleum products and nuclear fuel & 0.51 & 0.41 & 1.12 & 1.02 & 1.00 & 0.70 \\
\hline 19 & Pharmaceuticals & 0.71 & 0.50 & -3.44 & -3.97 & 3.00 & -0.19 \\
\hline 20 & Chemicals excluding pharmaceuticals & 2.97 & 0.76 & 2.07 & 2.05 & 1.12 & 1.75 \\
\hline 21 & Rubber and plastics products & 1.55 & 1.56 & -0.33 & -0.87 & 0.91 & 0.80 \\
\hline 22 & Other non-metallic mineral products & 1.80 & 0.64 & 0.27 & -0.23 & 1.78 & 0.92 \\
\hline 23 & Basic metals & 1.33 & 1.29 & 0.93 & 0.82 & 0.54 & 1.05 \\
\hline 24 & Fabricated metal products & 1.26 & 0.74 & -0.55 & -0.75 & 0.66 & 0.47 \\
\hline 25 & Machinery, nec & 2.77 & 0.18 & 1.79 & 1.35 & 2.62 & 1.61 \\
\hline 26 & Office, accounting and computing machinery & -0.61 & 3.01 & 3.24 & 2.42 & 2.26 & 1.76 \\
\hline 27 & Insulated wire & -3.02 & -1.05 & 2.62 & 2.03 & 1.14 & -0.37 \\
\hline 28 & Other electrical machinery and apparatus nec & 3.55 & 2.17 & 0.89 & 0.23 & 2.79 & 2.13 \\
\hline 29 & Electronic valves and tubes & 1.06 & -1.83 & 4.32 & 4.30 & 3.05 & 1.42 \\
\hline 30 & Telecommunication equipment & 5.96 & -0.76 & 4.53 & 3.78 & 3.87 & 3.04 \\
\hline 31 & Radio and television receivers & -0.27 & 2.11 & 2.47 & 0.43 & 6.45 & 1.80 \\
\hline 32 & Scientific instruments & 1.71 & 0.21 & 1.88 & 2.00 & 1.45 & 1.30 \\
\hline 33 & Other instruments & - & - & - & - & - & - \\
\hline 34 & Motor vehicles, trailers and semi-trailers & -1.60 & 1.56 & 1.47 & 0.58 & 2.36 & 0.61 \\
\hline 35 & Building and repairing of ships and boats & -3.59 & 1.12 & 2.53 & 1.91 & 1.43 & 0.14 \\
\hline 36 & Aircraft and spacecraft & -1.86 & 2.56 & -16.72 & -16.29 & -1.46 & -4.83 \\
\hline 37 & Railroad equipment and transport equipment nec & -1.82 & -0.10 & 0.66 & 0.00 & 0.68 & -0.39 \\
\hline 38 & Manufacturing nec & 0.90 & 1.97 & -0.38 & -0.81 & 0.68 & 0.72 \\
\hline 39 & Recycling & - & - & - & - & - & - \\
\hline
\end{tabular}


Table A-2 Sectoral TFP Growth in Service (\%)

\begin{tabular}{|c|c|c|c|c|c|c|c|}
\hline \multirow[t]{2}{*}{ Code } & \multirow[t]{2}{*}{ Industry } & \multirow[t]{2}{*}{$71-' 79$} & \multirow[t]{2}{*}{ 80-'89 } & \multirow[t]{2}{*}{ 90-'99 } & $\begin{array}{l}\text { Before } \\
\text { crisis }\end{array}$ & $\begin{array}{l}\text { After } \\
\text { crisis }\end{array}$ & \multirow[t]{2}{*}{ 71-'04 } \\
\hline & & & & & $90-' 98$ & 99-'04 & \\
\hline 40 & Electricity supply & 4.06 & 2.48 & 1.14 & 0.94 & 15.18 & 4.73 \\
\hline 41 & Gas supply & 18.85 & 16.06 & 9.71 & 9.82 & 1.23 & 12.14 \\
\hline 42 & Water supply & 9.08 & 3.67 & -5.72 & -5.92 & -1.50 & 1.65 \\
\hline 43 & Construction & -0.56 & -0.06 & -1.49 & -1.50 & -0.80 & -0.70 \\
\hline 44 & $\begin{array}{l}\text { Sale, maintenance and repair of motor vehicles and } \\
\text { motorcycles }\end{array}$ & 1.35 & -2.53 & 1.07 & 0.92 & 4.10 & 0.58 \\
\hline 45 & Wholesale trade and commission trade & -3.34 & 2.00 & -3.61 & -3.88 & -0.57 & -1.42 \\
\hline 46 & Retail trade & 1.82 & -4.74 & 0.32 & 1.35 & -0.75 & -0.69 \\
\hline 47 & Hotels and restaurants & -12.18 & -2.09 & -3.18 & -3.69 & -1.62 & -5.10 \\
\hline 48 & Inland transport & 3.16 & 1.59 & 1.34 & 0.68 & 2.97 & 2.01 \\
\hline 49 & Water transport & 0.03 & 3.60 & 14.48 & 16.15 & 0.25 & 5.39 \\
\hline 50 & Air transport & -7.48 & 1.95 & 2.09 & 2.57 & 4.07 & -0.01 \\
\hline 51 & Supporting and auxiliary transport activities & 8.39 & -1.09 & -5.81 & -6.79 & 2.97 & 0.62 \\
\hline 52 & Post and telecommunications & 6.98 & 3.58 & 8.17 & 7.74 & 6.47 & 6.09 \\
\hline 53 & $\begin{array}{l}\text { Financial intermediation, except insurance and pension } \\
\text { funding }\end{array}$ & 4.81 & 5.22 & -2.12 & -2.83 & 2.83 & 2.56 \\
\hline 54 & $\begin{array}{l}\text { Insurance and pension funding, except compulsory } \\
\text { social security }\end{array}$ & 11.75 & 3.47 & 5.45 & 9.77 & 0.61 & 5.77 \\
\hline 55 & Activities related to financial intermediation & - & 17.89 & 5.41 & -0.25 & 5.30 & 4.63 \\
\hline 56 & Imputation of owner occupied rents & -10.86 & -6.74 & -8.88 & -6.80 & -11.19 & -8.63 \\
\hline 57 & Other real estate activities & -14.85 & -0.47 & -7.81 & -7.37 & -7.79 & -7.39 \\
\hline 58 & Renting of machinery and equipment & -2.23 & 10.38 & 5.50 & 9.32 & -8.10 & 3.50 \\
\hline 59 & Computer and related activities & -5.28 & 6.80 & 5.11 & 4.85 & -1.71 & 1.59 \\
\hline 60 & Research and development & -9.61 & 6.17 & -1.36 & -0.75 & 1.38 & -0.68 \\
\hline 61 & Legal, technical and advertising & -3.56 & 2.24 & -6.35 & -7.14 & -0.30 & -2.23 \\
\hline 62 & Other business activities, nec & 6.13 & 0.56 & 2.61 & 2.85 & -31.19 & -2.96 \\
\hline 63 & Public admin and defense; compulsory social security & -4.84 & -2.10 & 0.58 & 0.50 & 0.37 & -1.70 \\
\hline 64 & Education & 6.52 & 1.08 & -0.74 & -0.47 & -1.37 & 1.68 \\
\hline 65 & Health and social work & -27.15 & 2.70 & 4.29 & 4.66 & -1.89 & -5.49 \\
\hline 66 & $\begin{array}{l}\text { Sewage and refuse disposal, sanitation and similar } \\
\text { activities }\end{array}$ & -3.96 & -1.00 & 3.16 & 1.59 & 1.47 & -0.66 \\
\hline 67 & Activities of membership organizations nec & 6.05 & -2.44 & -3.66 & -2.69 & -3.24 & -0.40 \\
\hline
\end{tabular}




\begin{tabular}{|l|l|c|c|c|c|c|c|}
\hline 68 & Media activities & 7.50 & -2.07 & -0.37 & -2.19 & 0.17 & 0.83 \\
\hline 69 & Other recreational activities & -4.55 & 1.35 & 7.85 & 1.38 & 1.12 & -0.25 \\
\hline 70 & Other service activities & -23.56 & -0.66 & -4.61 & -1.87 & -21.19 & -10.67 \\
\hline 71 & Private households with employed persons & 1.38 & -5.12 & 1.08 & 0.83 & -0.47 & -1.00 \\
\hline 72 & Extra-territorial organizations and bodies & - & - & - & - & - & - \\
\hline
\end{tabular}

